\title{
Antidiabetic and antiplatelet aggregation study of various methanol fractions of Nymphaea stellata Willd. leaves
}

\author{
MOHAN MARUGA RAJA ${ }^{1 *}$, SHRI HARI MISHRA², RIYAJ SHAUKAT TAMBOLI², DEVARAJAN \\ AGILANDESWARI $^{1}$
}

${ }^{1}$ Department of Pharmacognosy and Phytochemistry Hillside College of Pharmacy and Research Centre

Raghuvanahalli 9

Kanakapura Main Road

Bengaluru-560062

Karnataka, India

${ }^{2}$ Department of Herbal Drug Technology

Faculty of Pharmacy

The Maharaja Sayajirao University of Baroda

G H Patel Building,

Donor's Plaza, Fatehgunj

Vadodara-390002

Gujarat, India

*corresponding author: phone: +91 7338562191, e-mail: mohanmarugaraja@gmail.com

\section{Summary}

Introduction: Nymphaea stellata Willd. (Nymphaeaceae) is traditionally used for the treatment of diabetes. Alcohol extract of N. stellata leaves has been reported for hypoglycaemic activity.

Objective: The aim of this study was to further investigate the different methanol fractions of N. stellata leaves for anti-diabetic activity and anti-platelet aggregation activity.

Methods: Methanol extract was fractioned in to unsaponified petroleum ether fraction of methanol extract (UPFME), chloroform fraction of methanol extract (CFME) and residual fraction of methanol extract (RFME). All fractions were evaluated for in vivo anti-diabetic activity (STZ-NAD-induced rat model), in vitro anti-diabetic activity (PTP1B inhibition study) and anti-platelet aggregation activity.

Results: UPFME showed significant changes in all studied parameters, compared to the diabetic control. UPFME also showed an $\mathrm{IC}_{50}$ value of $19.30 \pm 1.1 \mathrm{mg} / \mathrm{ml}$ and $13.11 \pm 0.7 \mu \mathrm{g} / \mathrm{ml}$ in PTP1B inhibition study and anti-platelet aggregation study, respectively. 
Conclusion: The study indicates that UPFME of N. stellata leaves exhibit anti-diabetic and anti-platelet aggregation activity.

Key words: STZ-NAD, PTP1B inhibition, ADP induced, co-TLC, histopathology

\section{INTRODUCTION}

Diabetes mellitus is a metabolic disorder with heterogeneous aetiologies characterized by chronic hyperglycaemia and disturbances of carbohydrate, fat and protein metabolism resulting from defects in insulin secretion, insulin action, or both [1]. The number of people with diabetes has risen from 108 million in 1980 to 422 million in 2014. Type 1 diabetes is characterized by deficient insulin production in the body and type 2 diabetes results from the body's ineffective use of insulin. Type 2 diabetes accounts for the vast majority of people with diabetes around the world [2]. Contemporary anti-diabetic drugs are used only for the management of type 2 diabetes. Hence, there is a need to search for more effective drug for the type 2 diabetes treatment.

Traditional herbal medicines are being prescribed widely in developing countries because of their timetested effectiveness and relatively low cost. Galega officinalis was found to be rich in guanidine, a substance with blood glucose-lowering activity that formed the chemical basis of metformin [3]. Therefore, it would be good to explore the medicinal plants traditionally used for the treatment of diabetes.

Nymphaea stellata Willd. (Nymphaeaceae) is commonly known as Indian blue water lily. It is an important and well-known medicinal plant, widely used in Ayurveda and Sidhha systems of medicine for the treatment of diabetes, inflammation, liver disorders, urinary disorders, menorrhagia, blenorrhagia, menstruation problems, aphrodisiac and bitter tonic [4]. Sterols, alkaloids, saponins, tannins and flavonoids are the major class of chemical constituents in N. stellata. Oleanolic acid, betulinic acid, gallic acid, $\beta$-carotene, lupeol and $\beta$-sitosterol has been reported from the methanol extract of leaves $[5,6]$. The alcohol extract of N. stellata leaves has been reported for hypoglycaemic activity [7]. Hence, the present work was carried out to further investigate the different methanol fractions for potential anti-diabetic activity.

The majority of evidence suggests that inhibiting protein tyrosine phosphatase $1 \mathrm{~B}$ (PTP1B) represents a highly promising approach in the treatment of diabetes [8]. Platelets play a key role in atherogenesis, and its thrombotic complications and measures, which lead to blockade of one or multiple pathways modulating platelet activation and aggregation processes, are pivotal in reducing ischemic risk in diabetic subjects $[9,10]$. Hence, different methanol fractions were also screened for PTP1B inhibition activity and anti-platelet aggregation activity.

\section{MATERIAL AND METHODS}

\section{Reagents and solvents}

All reagents used were of analytical grade or HPLC grade and were purchased from Sigma-Aldrich, Spectrochem and Merck.

\section{Plant material}

Leaves of $N$. stellata were collected on October 2010 from Coonoor and Ootacamund, Tamil Nadu, India. The plant material was identified and authenticated by Dr. A. Rajan, Field Botanist, The Survey of Medicinal Plants and Collection Unit, Government Arts College, Ootacamund, Tamil Nadu, India. A voucher specimen (Pharmacy/HDT/NS/10-11/MKM/07) has been deposited in the Herbarium of Medicinal Plants, Faculty of Pharmacy, The Maharaja Sayajirao University of Baroda, Vadodara, Gujarat, India.

\section{Preparation of extract and fractions}

Air-dried leaves (2000 g) of N. stellata were grounded and extracted with methanol in Soxhlet apparatus for $48 \mathrm{~h}$. The extract was concentrated under reduced pressure on a rotary evaporator (Rotavapor, Buchi) and dried in a desiccator to yield methanol extract. The methanol extract was next fractioned by centrifuging with $3 \times 500 \mathrm{ml}$ of petroleum ether $\left(60-80^{\circ} \mathrm{C}\right)$ at $1000 \mathrm{~g}$ for $15 \mathrm{~min}$. The supernatants were combined, concentrated and dried to yield petroleum ether fraction of methanol extract. The residue was subsequently fractioned by centrifuging with $3 \times 500 \mathrm{ml}$ of chloroform as mentioned above. The supernatants were combined, concentrated and dried to yield chloroform fraction of methanol extract (CFME). The 
insoluble residue was designated as residual fraction of methanol extract (RFME). The petroleum ether fraction of methanol extract was saponified as per the reported procedure [11] and the unsaponified matter was designated as unsaponified petroleum ether fraction of methanol extract (UPFME).

\section{Animals}

Healthy adult Albino rats of Wistar strain weighing 200-250 g were procured from Zydus-Cadila Pharmaceuticals, Ahmedabad. The animal house was well ventilated and rats had $12 \pm 1 \mathrm{~h}$ day and night cycle at $25 \pm 3^{\circ} \mathrm{C}$ and $35-55 \%$ relative humidity. Rats were fed with rat pellet feed supplied by Nav-Maharashtra Oil Mills, Maharashtra, India and water ad libitum. Animal experiments were carried out as per the guidelines of Institutional Animal Ethical Committee, Faculty of Pharmacy, The Maharaja Sayajirao University of Baroda, Vadodara, Gujarat, India (IAEC Reg. No. 404/01/a/CPCSEA).

\section{Acute oral toxicity study}

Toxicity study was conducted as per internationally accepted protocol drawn under OECD guidelines 423 in Albino rats of Wistar strain. Different groups were administered with UPFME, CFME and RFME at four dose levels $(5,50,300$ and $2000 \mathrm{mg} / \mathrm{kg} B W$, p.o.) as a fine suspension in $2 \%$ gum acacia. Rats administered with vehicle served as control group.

\section{Anti-diabetic study}

Experimental type 2 diabetes was induced as per Masiello et al. [12] with streptozotocin-nicotinamide (STZ-NAD). STZ and NAD were procured from Himedia Laboratories Ltd, Mumbai, India. The blood glucose levels were determined at $72 \mathrm{~h}$ and the rats with fasting blood glucose concentration of more than $180 \mathrm{mg} / \mathrm{dl}$ were considered diabetic and selected for the anti-diabetic study. The selected animals were divided into 9 groups $(\mathrm{n}=6)$. Normal rats were administered with $0.5 \mathrm{ml} / 100 \mathrm{~g}, B W$ of saline in group I. Diabetic rats were administered with $0.5 \mathrm{~m} / 100 \mathrm{~g}, B W$ of saline in group II. Diabetic rats were administered with $50 \mathrm{mg} / \mathrm{kg}, B W$ of metformin [13] in group III. Diabetic rats were administered with 100 and $200 \mathrm{mg} / \mathrm{kg}, B W$ of UPFME in group IV and V, respectively. Diabetic rats were administered with 100 and $200 \mathrm{mg} / \mathrm{kg}, B W$ of RFME in group VI and VII, respectively. Diabetic rats were administered with 100 and $200 \mathrm{mg} / \mathrm{kg}, B W$ of CFME in group VIII and IX respectively. Saline, metformin and fractions were administered orally once a day for 30 days. The effects of different groups were determined by measuring fasting plasma glucose [14], fasting plasma insulin levels [15] and changes in body weight. On $31^{\text {st }}$ day the rats were sacrificed and liver was isolated for the estimation of hexokinase [16], glucose-6-phosphatase [17] and glycogen [18]. Pancreas was also removed to study the histological changes in different groups. Liver and pancreas tissues were washed with normal saline and stored in $10 \%$ formalin. The pancreatic tissue was processed for paraffin embedding and sections were stained with haematoxylin-eosin reagent. The histological results were recorded as microphotographs and examined for intracellular changes.

\section{Identification of reported compounds in UP- FME by comparative thin layer chromatogra- phy (Co-TLC) method}

Previously reported compounds like oleanolic acid, betulinic acid, gallic acid, $\beta$-carotene, lupeol and $\beta$-sitosterol from methanol extract of leaves $[5,6]$ were procured from Himedia Laboratories Pvt. Ltd., Mumbai, India and Sigma Chemicals, Bangalore, India. Co-TLC method was preformed with all the reported compounds and UPFME.

\section{PTP1B inhibition study}

PTP1B inhibitory activity was tested by using Calbiochem PTP1B colorimetric assay kit (User Protocol; 2008, Catalogue No: 539736, USA). The absorbance was measured at $620 \mathrm{~nm}$ on microplate ELISA reader (BioRad-680XR) and the results were expressed as the amount of phosphate released in $\mathrm{nM}$.

\section{Anti-platelet aggregation study}

In vitro ADP induced platelet aggregation activity was carried out using heparin-treated whole blood obtained from healthy anaesthetized rats by electrical impedance method using Chrono-Log Model 592VS dual channel whole blood aggregometer (Chrono-Log Corporation, Haverton, PA, USA) [19]. Each reading was taken in triplicate with 
different concentrations of samples, taking control and the respective concentration of aspirin for comparative reading each time. The 50\% inhibition of platelet aggregation was determined for each test sample comparing with the control and $\mathrm{IC}_{50}$ values was calculated accordingly in $\mu \mathrm{M}$ for standard and $\mu \mathrm{g} / \mathrm{ml}$ for fractions.

\section{Statistical analysis}

The quantitative measurements in all the experiments were made on 6 rats in each group and the values are expressed as mean \pm standard deviation. Graphpad Instat Version 4 software was used. Data were subjected to the analysis of variance (one way ANOVA) to determine the significance of changes followed by Dunnett's test for multiple comparisons.

\section{RESULTS AND DISCUSSION}

\section{Percentage yield of extracts and fractions}

The percentage yield of methanol extract, petroleum ether fraction of methanol extract, UPFME, CFME and RFME were found to be 22.44, 19.17, 17.63, 11.23 and $69.04 \% w / w$, respectively.

\section{Acute oral toxicity study}

The acute toxicity study was performed for establishing the therapeutic index. The fractions showed no signs of toxicity up to a dose of $2000 \mathrm{mg} / \mathrm{kg}$.

\section{Anti-diabetic study}

The diabetic control group showed a marked increase in plasma glucose and a reduction in insulin level. UPFME $200 \mathrm{mg} / \mathrm{kg}$ and metformin treated group showed significant $(p<0.01)$ restoration of glucose and insulin levels when compared to the diabetic control group. CFME and RFME treated groups at both dose levels did not show any significant change (tab. 1).

It has been suggested that bioactive compounds from plant sources having anti-hyperglycaemic activities might act by several mechanisms such as stimulation of insulin secretion, increasing the repair or proliferation of $\beta$-cells and enhancing the effects of insulin [20]. Hence, the significant decrease in the glucose level and increase in insulin level of diabetic rats treated with UPFME may be due to the stimulation of insulin secretion from the remnant $\beta$-cells or regenerated $\beta$-cells or both [21].

Metformin and UPFME $200 \mathrm{mg} / \mathrm{kg}$ treated groups showed a significant $(p<0.01)$ increase in hexokinase level (tab. 2). The activation of glycolysis may be the reason for the significant increase of hexokinase in UPFME $200 \mathrm{mg} / \mathrm{kg}$ treated rats.

Metformin and UPFME $200 \mathrm{mg} / \mathrm{kg}$ treated groups showed significant $(p<0.01)$ decrease in glucose-6-phosphatase level (tab. 2). The decreased levels of glucose-6-phosphatase observed in UPFME treated diabetic rats may be due to the regulation of gluconeogenic enzymes.

The hepatic glycogen content of diabetic control group was reduced significantly as compared to other groups. Metformin and UPFME (100 mg/kg and $200 \mathrm{mg} / \mathrm{kg}$ ) treated groups showed significant $(p<0.01)$ restoration of the depleted glycogen level than other groups (tab. 2). The prevention of liver glycogen depletion in UPFME treated groups may be due to stimulation of insulin release from $\beta$-cells.

STZ-NAD induced diabetes is associated with a characteristic loss of body weight which is due to increased muscle wasting in diabetic state [22]. Metformin and UPFME $200 \mathrm{mg} / \mathrm{kg}$ treated groups showed significant $(p<0.01)$ restoration of body weight (tab. 3 ). The improved carbohydrate and lipid metabolism may be the reason for increased body weight.

Diabetic control group showed shrunken islets of Langerhans with disrupted cellular architecture and disarray of acinar structure. Significant reduction in total number of cells per pancreatic islet with marked degranulation was also observed. This provides clear evidence that the pancreatic $\beta$-cells have been destroyed in diabetic control group (fig. 1b) when compared to the intact $\beta$-cells in normal control group (fig. 1a). The metformin treated group showed significant higher number of cells per islet with its cellular architecture preserved. It also showed no degranulation and vacuoles (fig. 1c).

UPFME $(100 \mathrm{mg} / \mathrm{kg})$ treated (fig. 1d), CFME (100 and $200 \mathrm{mg} / \mathrm{kg}$ ) treated (fig. If and $1 \mathrm{~g}$ ) and RFME (100 and $200 \mathrm{mg} / \mathrm{kg}$ ) treated groups (fig. $1 \mathrm{~h}$ and 1i) showed shrunken islet with disrupted cellular architecture. They also showed significant reduction in total number of cells per islet and more vacuoles. UPFME $(200 \mathrm{mg} / \mathrm{kg})$ treated groups showed relatively intact, larger size islet and reduced vacuoles (fig. 1e). Significant increase in number of cells per islet in UPFME $(200 \mathrm{mg} / \mathrm{kg})$ treated group suggests regeneration of pancreatic islet cells. 


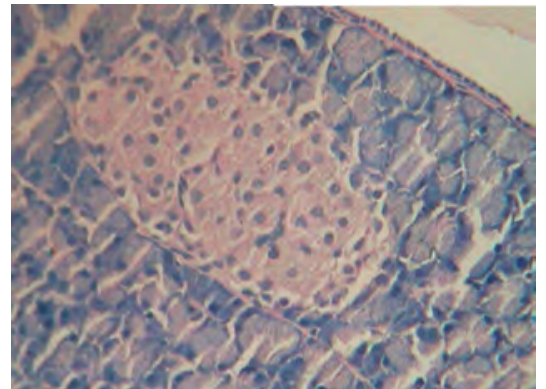

(a) Normal control group

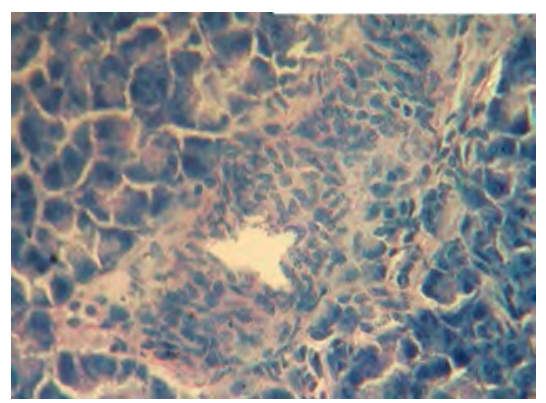

(c) Metformin treated group

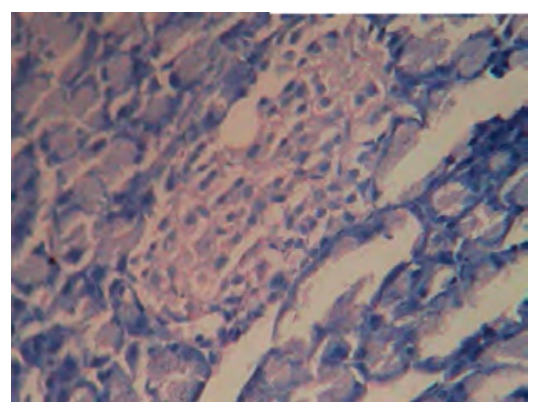

(e) UPFME (200 mg/kg) treated group

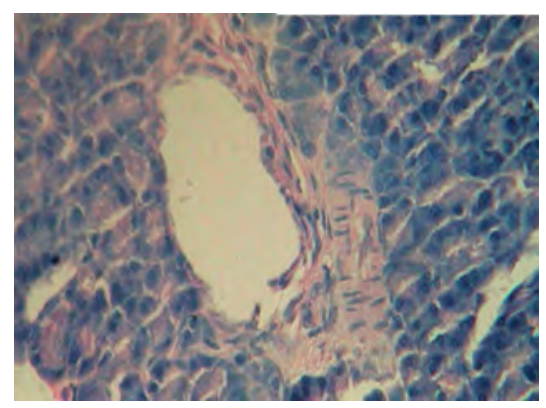

(g) CFME $(200 \mathrm{mg} / \mathrm{kg})$ treated group

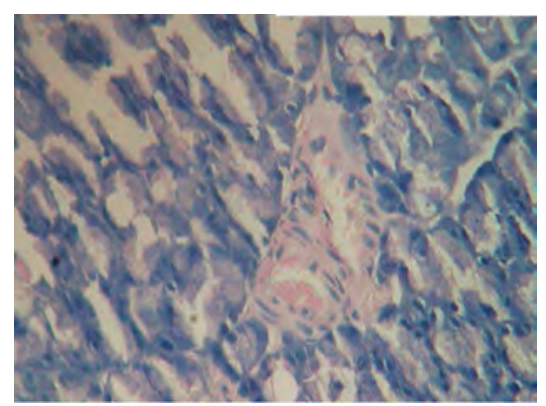

(i) RFME (200 mg/kg) treated group

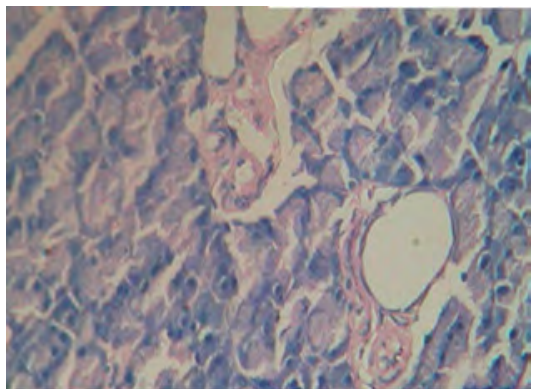

(b) Diabetic control group

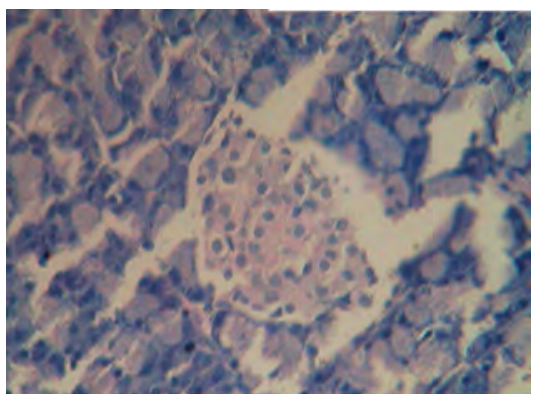

(d) UPFME (100 mg/kg) treated group

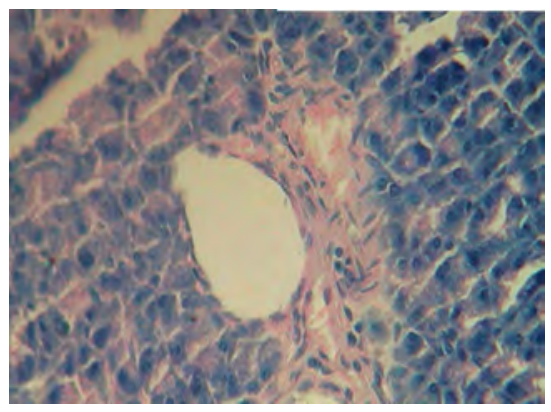

(f) CFME (100 mg/kg) treated group

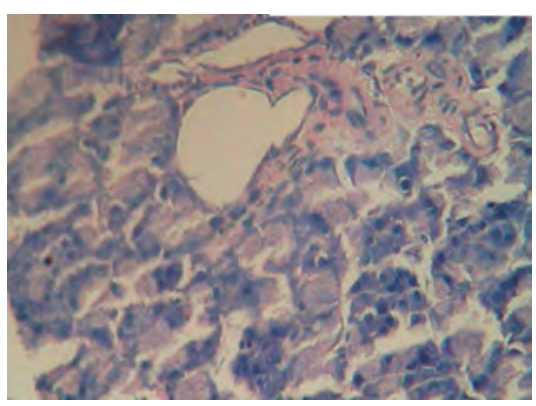

(h) RFME (100 mg/kg) treated group

Figure 1.

Histological studies showing changes in the endocrine and exocrine pancreas of normal, diabetic, standard and Nymphaea stellata fractions treated groups 
Table 1.

Plasma glucose and insulin level changes in normal, diabetic, standard and Nymphaea stellata fractions treated groups

\begin{tabular}{|c|c|c|}
\hline Groups & Plasma glucose $[\mathrm{mg} / \mathrm{dl}]$ & Plasma insulin $[\mu \mathrm{U} / \mathrm{ml}]$ \\
\hline I (Normal control) & $87.04 \pm 4.86^{\star *}$ & $16.59 \pm 2.02^{\star *}$ \\
\hline II (Diabetic control) & $275.34 \pm 28.86$ & $4.86 \pm 1.05$ \\
\hline III (Metformin 50 mg/kg) & $145.26 \pm 24.22$ ** & $14.56 \pm 1.54^{\star *}$ \\
\hline IV (UPFME 100 mg/kg) & $240.54 \pm 14.34^{*}$ & $7.01 \pm 0.89$ * \\
\hline V (UPFME 200 mg/kg) & $190.57 \pm 21.57^{* *}$ & $11.58 \pm 1.07^{\star *}$ \\
\hline VI (CFME 100 mg/kg) & $262.59 \pm 12.19^{\mathrm{ns}}$ & $6.47 \pm 0.87^{\mathrm{ns}}$ \\
\hline VII (CFME 200 mg/kg) & $250.67 \pm 13.51^{\mathrm{ns}}$ & $6.01 \pm 1.47^{\text {ns }}$ \\
\hline VIII (RFME 100 mg/kg) & $265.49 \pm 10.53^{\text {ns }}$ & $5.16 \pm 1.27^{\mathrm{ns}}$ \\
\hline IX (RFME 200 mg/kg) & $255.31 \pm 15.11^{\text {ns }}$ & $5.94 \pm 1.01^{\text {ns }}$ \\
\hline
\end{tabular}

Value are means \pm standard deviation $(\mathrm{n}=6) ;^{*}-p<0.05 ;{ }^{* *}-p<0.01$; ${ }^{\text {ns }}-$ not significant.

Table 2.

Changes in hepatic hexokinase, glucose-6-phosphatase and liver glycogen levels in normal, diabetic, standard and Nymphaea stellata fractions treated groups

\begin{tabular}{|c|c|c|c|}
\hline Groups & $\begin{array}{c}\text { Hexokinase } \\
\text { [U/g/min] }\end{array}$ & $\begin{array}{l}\text { Glucose-6- } \\
\text { phosphatase } \\
\text { [U/g/min] }\end{array}$ & $\begin{array}{c}\text { Liver glycogen } \\
\text { [ } \mu \text { g of glucose } / \mathrm{mg} \\
\text { of wet tissue] }\end{array}$ \\
\hline I (Normal control) & $10.51 \pm 1.97^{* *}$ & $14.82 \pm 2.57^{* *}$ & $53.78 \pm 2.18^{\star *}$ \\
\hline II (Diabetic control) & $2.24 \pm 1.69$ & $35.38 \pm 6.54$ & $25.13 \pm 3.21$ \\
\hline III (Metformin 50 mg/kg) & $8.54 \pm 1.1^{\star *}$ & $19.35 \pm 5.67^{* *}$ & $52.24 \pm 1.28^{\star *}$ \\
\hline IV (UPFME 100 mg/kg) & $3.12 \pm 0.85^{\text {ns }}$ & $26.15 \pm 4.57^{\star}$ & $34.15 \pm 3.31^{\star \star}$ \\
\hline V (UPFME 200 mg/kg) & $5.67 \pm 0.48^{\star *}$ & $23.68 \pm 3.58^{* *}$ & $40.11 \pm 2.12^{\star *}$ \\
\hline VI (CFME 100 mg/kg) & $2.75 \pm 1.12^{\mathrm{ns}}$ & $33.65 \pm 5.47^{\mathrm{ns}}$ & $27.94 \pm 4.11^{\mathrm{ns}}$ \\
\hline VII (CFME 200 mg/kg) & $3.12 \pm 1.87^{\text {ns }}$ & $30.27 \pm 3.69^{\mathrm{ns}}$ & $28.12 \pm 3.21^{\mathrm{ns}}$ \\
\hline VIII (RFME 100 mg/kg) & $2.98 \pm 1.68^{\text {ns }}$ & $34.65 \pm 4.19^{\mathrm{ns}}$ & $28.04 \pm 5.27^{\text {ns }}$ \\
\hline IX (RFME 200 mg/kg) & $3.15 \pm 0.81^{\text {ns }}$ & $29.68 \pm 3.31^{\mathrm{ns}}$ & $29.11 \pm 5.61^{\mathrm{ns}}$ \\
\hline
\end{tabular}

Value are means \pm standard deviation $(\mathrm{n}=6) ;^{*}-p<0.05 ;{ }^{* *}-p<0.01 ;^{\text {ns }}-$ not significant.

Table 3.

Body weight changes in normal, diabetic, standard and Nymphaea stellata fractions treated groups

\begin{tabular}{ll}
\hline Groups & Body weight $[\mathrm{g}]$ \\
\hline I (Normal control) & $226.13 \pm 4.57^{* *}$ \\
\hline II (Diabetic control) & $165.24 \pm 9.56$ \\
\hline III (Metformin $50 \mathrm{mg} / \mathrm{kg})$ & $220.35 \pm 4.87^{\text {** }}$ \\
\hline IV (UPFME $100 \mathrm{mg} / \mathrm{kg})$ & $174.84 \pm 5.66^{\mathrm{ns}}$ \\
\hline V (UPFME $200 \mathrm{mg} / \mathrm{kg})$ & $190.22 \pm 5.12^{\text {** }}$ \\
\hline VI $($ CFME $100 \mathrm{mg} / \mathrm{kg})$ & $170.35 \pm 7.11^{\text {ns }}$ \\
\hline VII $($ CFME $200 \mathrm{mg} / \mathrm{kg})$ & $171.94 \pm 4.59^{\text {ns }}$ \\
\hline VIII (RFME $100 \mathrm{mg} / \mathrm{kg})$ & $168.22 \pm 3.67^{\text {ns }}$ \\
\hline IX (RFME $200 \mathrm{mg} / \mathrm{kg})$ & $171.41 \pm 6.66^{\text {ns }}$ \\
\hline
\end{tabular}

Value are means \pm standard deviation $(\mathrm{n}=6)$; ${ }^{*}-p<0.01$; ${ }^{\text {ns }}-$ not significant.
The overall results show that CFME and RFME at both dose levels $(100 \mathrm{mg} / \mathrm{kg}$ and $200 \mathrm{mg} / \mathrm{kg})$ are completely inactive. UPFME has shown nearly comparable effect to that of metformin on all the studied parameters.

\section{Identification of reported compounds in UP- FME by comparative thin layer chromatogra- phy (Co-TLC) method}

The Co-TLC studies were performed between the compounds viz. oleanolic acid, betulinic acid, gallic acid, $\beta$-carotene, lupeol and $\beta$-sitosterol with UPFME separately in different mobile phases. The presences of reported compounds were confirmed by comparing their $\mathrm{R}_{\mathrm{f}}$ values with UPFME (tab. 4). 
Anti-hyperglycaemic effect of oleanolic acid [23], $\beta$-carotene [24], lupeol [25] and $\beta$-sitosterol [26] may have contributed synergistically to the observed anti-diabetic activity of UPFME. Increased body weight observed in UPFME treated rats may also be due to the antidyslipidemic activity of betulinic acid [27] and lupeol [25]. The signs of $\beta$-cell regeneration in the histopatholgical study may also be due to the antioxidant effect of $\beta$-carotene and/or gallic acid present in UPFME. From the results, it may also be postulated that at least more than one constituent with diversified mechanism of actions may be the reason for the total anti-diabetic activity of UPFME.

\section{PTP1B inhibition study}

Suramin is a reversible and competitive inhibitor of PTP1B. UPFME showed the highest potency of PTP1B inhibition with an $\mathrm{IC}_{50}$ value of $19.30 \pm 1.1 \mu \mathrm{g} / \mathrm{ml}$ among the other fractions (tab. 5). Oleanolic acid [28], betulinic acid [29] and lupeol
[30] has been previously reported for PTP1B inhibition activity. The activity of UPFME may be due to the synergistic action of oleanolic acid, betulinic acid and lupeol. The in vitro PTP1B inhibition of UPFME overlaps with its in vivo anti-diabetic activity.

\section{Anti-platelet aggregation study}

Aspirin and UPFME inhibited platelet aggregation with an $\mathrm{IC}_{50}$ value of $10.14 \pm 0.7 \mu \mathrm{M}$ and $13.11 \pm 0.7 \mu \mathrm{g} / \mathrm{ml}$ respectively (tab. 6). The exhibited activity of UPFME can be attributed to the antiplatelet aggregation activity of oleanolic acid [31] and gallic acid [32]. CFME and RFME increased aggregation of platelets.

\section{CONCLUSION}

The anti-diabetic activity (in vivo and in vitro) and anti-platelet aggregation activity of UPFME from

Table 4.

Identification of reported compounds in UPFME by co-TLC method

\begin{tabular}{|c|c|c|c|}
\hline Samples/standards & $\mathrm{R}_{\mathrm{f}}$ & Mobile phase & Derivatisation agent \\
\hline UPFME & 0.53 & \multirow{2}{*}{$\begin{array}{l}\text { Toluene-ethyl acetate-glacial acetic acid } \\
(7: 3: 0.1 v / v / v)\end{array}$} & \multirow[t]{2}{*}{ Anisaldehyde sulphuric acid reagent } \\
\hline Oleanolic acid & 0.53 & & \\
\hline UPFME & 0.56 & \multirow{2}{*}{$\begin{array}{l}\text { Toluene-ethyl acetate-glacial acetic acid } \\
(7: 3: 0.03 v / v / v)\end{array}$} & \multirow[t]{2}{*}{ Anisaldehyde sulphuric acid reagent } \\
\hline Betulinic acid & 0.56 & & \\
\hline UPFME & 0.26 & \multirow{2}{*}{$\begin{array}{l}\text { Toluene-ethyl acetate-methanol-formic acid } \\
(6: 3: 1: 0.5 v / v / v / v)\end{array}$} & \multirow[t]{2}{*}{ Visible in short UV (254 nm) } \\
\hline Gallic acid & 0.26 & & \\
\hline UPFME & 0.39 & \multirow{2}{*}{$\begin{array}{l}\text { Hexane-benzene } \\
(9: 1 v / v)\end{array}$} & \multirow[t]{2}{*}{ Visible in normal light } \\
\hline$\beta$-Carotene & 0.39 & & \\
\hline UPFME & 0.40 & \multirow{2}{*}{$\begin{array}{l}\text { Toluene-chloroform-ethyl acetate-glacial acetic } \\
\text { acid }(10: 2: 1: 0.03 v / v / v / v)\end{array}$} & \multirow[t]{2}{*}{ Antimony trichloride reagent } \\
\hline Lupeol & 0.40 & & \\
\hline UPFME & 0.57 & \multirow{2}{*}{$\begin{array}{l}\text { Toluene-chloroform-methanol } \\
(4: 4: 1 \quad v / v / v)\end{array}$} & \multirow[t]{2}{*}{ Anisaldehyde sulphuric acid reagent } \\
\hline$\beta$-Sitosterol & 0.57 & & \\
\hline
\end{tabular}

Table 5.

PTP1B inhibitory effect of standard and fractions of Nymphaea stellata

\begin{tabular}{lc}
\hline Standard/fractions & $\mathrm{IC}_{50}$ \\
\hline Suramin & $5.37 \pm 0.6 \mu \mathrm{M}$ \\
\hline UPFME & $19.30 \pm 1.1 \mu \mathrm{g} / \mathrm{ml}$ \\
\hline CFME & $46.33 \pm 1.2 \mu \mathrm{g} / \mathrm{ml}$ \\
\hline RFME & $95.11 \pm 1.4 \mu \mathrm{g} / \mathrm{ml}$ \\
\hline
\end{tabular}

Value are means \pm standard deviation $(\mathrm{n}=3)$.
Table 6.

Effects of standard and fractions of Nymphaea stellata on ADP induced platelet aggregation

\begin{tabular}{lc}
\hline Standard/fractions & $\mathrm{IC}_{50}$ \\
\hline Aspirin & $10.14 \pm 0.7 \mu \mathrm{M}$ \\
\hline UPFME & $13.11 \pm 0.7 \mu \mathrm{g} / \mathrm{ml}$ \\
\hline CFME & Induced aggregation \\
\hline RFME & Induced aggregation \\
\hline
\end{tabular}

Value are means \pm standard deviation $(\mathrm{n}=3)$. 
$N$. stellata leaves is due to its synergistic multi-target effect. The currently marketed drugs for type 2 diabetes are based on the so-called "one-molecule-onetarget" paradigm. However, due to the multi-factorial pathogenesis of the disease, drugs that hit more than one biological target may offer a better pharmacological approach.

\section{ACKNOWLEDGEMENT}

The authors thank Faculty of Pharmacy, The Maharaja Sayajirao University of Baroda, Vadodara, Gujarat, India for providing the facilities for the successful completion of this research project.

Conflict of interest: Authors declare no conflict of interest.

\section{REFERENCES}

1. World Health Organization. Use of Glycated Haemoglobin (HbAlc) in the Diagnosis of Diabetes. Geneva. WHO Press, 2011:4. http://www.who. int/diabetes/publications/report-hba1c_2011. pdf?ua $=1$

2. World Health Organization. Global Report on Diabetes. Geneva. WHO Press, 2016:11-21. http:// apps.who.int/iris/bitstream/10665/204871/ 1/9789241565257_eng.pdf

3. Bailey CJ, Day C. Metformin: its botanical background. Practical Diabetes 2004; 21(3):115-117. doi: http://dx.doi.org/10.1002/pdi.606

4. Raja MK, Sethiya NK, Mishra SH. A Comprehensive review on Nymphaea stellata: A traditionally used bitter. J Adv Pharm Technol Res 2010; 1(3):311-319. doi: http://dx.doi. org/10.4103/0110-5558.72424

5. Agilandeswari D. Quantification of oleanolic acid and betulinic acid by TLC and brine shrimp lethality assay of Nymphaea stellata Willd. leaves. Int J Pharm Chem Biol Sci 2012; 2(2):166-173. http://www.ijpcbs.com/files/volume2-2-2012/7.pdf

6. Agilandeswari D. HPTLC studies and brine shrimp lethality assay of extracts, fractions and identified compounds of Nymphaea stellata Willd. leaves. Int J Pharm Indus Res 2012; 2(1):19-25.
7. Dhanabal SP, Raja MK, Ramanathan M, Suresh B. Hypoglycemic activity of Nymphaea stellata leaves ethanolic extract in alloxan induced diabetic rats. Fitoterapia 2007; 78(4):288-291. doi: http://dx.doi.org/10.1016/j.fitote.2007.02. 009

8. Ma J, Li Z, Xing S, Ho WT, Fu X, Zhao ZJ. Tea contains potent inhibitors of tyrosine phosphatase PTP1B. Biochem Biophys Res Commun 2011; 407(1):98-102. doi: http://dx.doi.org/10.1016/j. bbrc.2011.02

9. Angiolillo DJ. Antiplatelet therapy in diabetes: Efficacy and limitations of current treatment strategies and future directions. Diabetes Care 2009; 32(4):531-540. doi: http://dx.doi.org/10.2337/ dc08-2064

10. Grove EL, Gregersen S. Antiplatelet therapy in patients with diabetes mellitus. Curr Vasc Pharmacol 2012; 10(4):494-505. doi: http://dx.doi. org/10.2174/157016112800812818

11. Khandelwal KR. Practical Pharmacognosy. $1^{\text {st }}$ ed. Pune. Nirali Prakashan, 2002:149.

12. Masiello P, Broca C, Gross R, Roye M, Manteghetti M, Hillaire-Buys D et al. Experimental NIDDM: development of a new model in adult rats administered streptozotocin and nicotinamide. Diabetes 1998; 47(2):224-229. doi: http:// dx.doi.org/10.2337/diab.47.2.224

13. Natarajan V, Arul Gnana Dhas AS. Effect of active fraction isolated from the leaf extract of Dregea volubilis [Linn.] Benth. on plasma glucose concentration and lipid profile in streptozotocin-induced diabetic rats. Springerplus 2013; 2:394. doi: http://dx.doi.org/10.1186/2193-1801-2-394

14. Trinder P. Determination of glucose in blood using glucose oxidase with an alternative oxygen acceptor. Ann Clin Biochem 1969; 6(1):24-27. doi: http://dx.doi.org/10.1177/0004563269006 00108

15. Yalow RS, Berson SA. Immunoassay of plasma insulin in man. Diabetes 1961; 10:339-344. doi: http://dx.doi.org/10.2337/diab.10.5.339

16. Brandstrup N, Kirk JE, Bruni C. The hexokinase and phosphoglucoisomerase activities of aortic and pulmonary artery tissue in 
individuals of various ages. J Gerontol 1957; 12(2):166-171. doi: http://dx.doi.org/10.1093/ geronj/12.2.166

17. Baginsky ES, Foa PP, Zad B. Glucose-6-phosphatase. In: Bergmeyer HU, ed. Methods of enzymatic analysis. $2^{\text {nd }}$ ed. New York. Academic Press, 1974:788-792.

18. Stafford RO, Barnes LE, Bowman BJ, Meinzinger MM. Glucocorticoid and mineralocorticoid activities of $\Delta^{1}$-fluoro-hydrocortisone. Proc Soc Exp Biol Med 1955; 89(3):371-374.

19. Giridhar R, Tamboli RS, Ramajayam R, Prajapati DG, Yadav MR. Assessment of antiplatelet activity of 2-aminopyrimidines. Eur J Med Chem 2012; 50:428-432. doi: http://dx.doi.org/10.1016/j.ejmech.2012.01.035

20. Fayed T, El-Missiry MA, Emara H, El-Sayaad N. Effect of Nigella sativa or fish oil supplementation in alloxan diabetic rats. J Union Arab Biol 1998; 9:237-250.

21. Pari L, Latha M. Antidiabetic activity of Cassia auriculata flowers: Effect on lipid peroxidation in streptozotocin diabetes rats. Pharm Biol 2002; 40(7):512-517. doi: http://dx.doi.org/10.1076/ phbi.40.7.512.14683

22. Swanston-Flatt SK, Day C, Bailey CJ, Flatt PR. Traditional plant treatments for diabetes: Studies in normal and streptozotocin diabetic mice. Diabetologia 1990; 33(8):462-464. doi: http://dx.doi. org/10.1007/BF00405106

23. Hao Z, Hang B, Wang, Y. Hypoglycemic effect of oleanolic acid. Zhongguo Yaoke Daxue Xuebao 1989; 22:210-212.

24. Attia AA. Histological and electron microscopic studies of the effect of $\beta$-carotene on the pancreas of streptozotocin (STZ) induced diabetic rats. Pak J Biol Sci 2009; 12(4):301-314. doi: http:// dx.doi.org/10.3923/pjbs.2009.301.314

25. Papi Reddy K, Singh AB, Puri A, Srivastava AK, Narender T. Synthesis of novel triterpenoid (lupeol) derivatives and their in vivo antihyperglycemic and antidyslipidemic activity. Bioorg Med
Chem Lett 2009 19(15):4463-4466. doi: http:// dx.doi.org/10.1016/j.bmcl.2009.05.034

26. Ivorra MD, D’Ocon MP, Paya M, Villar A. Antihyperglycemic and insulin releasing effects of $\beta$-sitosterol 3- $\beta$-D-glucoside and its aglycone, $\beta$-sitosterol. Arch Int Pharmacodyn Ther 1988; 296:224-231.

27. De Melo CL, Queiroz MG, Arruda Filho AC, Rodrigues AM, De Sousa DF, Almeida JG et al. Betulinic acid, a natural pentacyclic triterpenoid, prevents abdominal fat accumulation in mice fed a high-fat diet. J Agric Food Chem 2009; 57(19):8776-8781. doi: http://dx.doi.org/10.1021/ jf900768w

28. Li YF, Hu LH, Lou FC, Li J, Shen Q. PTP1B inhibitors from Ardisia japonica. J Asian Nat Prod Res 2005; 7(1):13-18. doi: http://dx.doi.org/10.10 80/10286020310001596033

29. Choi JY, Na M, Hyun Hwang I, Ho Lee S, Young Bae E, Yeon Kim B et al. 2009. Isolation of betulinic acid, its methyl ester and guaiane sesquiterpenoids with protein tyrosine phosphatase $1 \mathrm{~B}$ inhibitory activity from the roots of Saussurea lappa C.B.Clarke. Molecules 2009; 14(1):266-272. doi: http://dx.doi.org/10.3390/ molecules14010266

30. Na M, Kim BY, Osada H, Ahn JS. Inhibition of protein tyrosine phosphatise $1 \mathrm{~B}$ by lupeol and lupenone isolated from Sorbus commixta. J Enzyme Inhib Med Chem 2009; 24(4):1056-1059. doi: http://dx.doi.org/10.1080/14756360802693312

31. Jin JL, Lee YY, Heo JE, Lee S, Kim JM, YunChoi HS. Anti-platelet pentacyclic triterpenoids from leaves of Campsis grandiflora. Arch Pharm Res 2004; 27(4):376-380. doi: http://dx.doi. org/10.1007/BF02980076

32. Appeldoorn CC, Bonnefoy A, Lutters BC, Daenens K, Van Berkel TJC, Hoylaerts MF et al. Gallic acid antagonizes P-selectin-mediated plateletleukocyte interactions: implications for the French paradox. Circulation 2005; 111(1):106-112. doi: http://dx.doi.org/10.1161/01.CIR.0000151307. 10576.02 


\title{
Studium działania przeciwcukrzycowego i antyagregacyjnego różnych frakcji wyciągu metanolowego z liści Nymphaea stellata Willd.
}

\author{
MOHAN MARUGA RAJA ${ }^{1 *}$, SHRI HARI MISHRA ${ }^{2}$, RIYAJ SHAUKAT TAMBOLI ${ }^{2}$, DEVARAJAN \\ AGILANDESWARI ${ }^{1}$
}

${ }^{1}$ Department of Pharmacognosy and Phytochemistry

Hillside College of Pharmacy and Research Centre

Raghuvanahalli 9

Kanakapura Main Road

Bengaluru-560062

Karnataka, India

${ }^{2}$ Department of Herbal Drug Technology

Faculty of Pharmacy

The Maharaja Sayajirao University of Baroda

G H Patel Building,

Donor's Plaza, Fatehgunj

Vadodara-390002

Gujarat, India

*corresponding author: phone: +91 7338562191, e-mail: mohanmarugaraja@gmail.com

\section{Streszczenie}

Wstęp: Nymphaea stellata Willd. (Nymphaceae) jest tradycyjnie stosowana w leczeniu cukrzycy. Istnieją doniesienia o działaniu hipoglikemicznym wyciągu alkoholowego z liści tej rośliny.

Cel: Celem pracy były dalsze badania właściwości przeciwcukrzycowych i antyagregacyjnych różnych frakcji metanolowego wyciągu z liści N. stellata.

Metodyka: Ekstrakt metanolowy frakcjonowano na niezmydloną frakcję otrzymaną za pomocą eteru naftowego (UMFME), frakcję otrzymaną za pomocą chloroformu (CFME) oraz pozostałość ekstraktu metanolowego (RFME). Wszystkie frakcję były badane w kierunku działania przeciwcukrzycowego in vivo (w modelu szczurzym cukrzycy wywołanej przy pomocy STZ-NAD), w kierunku aktywności przeciwcukrzycowej w badaniach in vitro (badania hamowania PTP1B) oraz w celu określenia aktywności antyagregacyjnej.

Wyniki: Stosowanie frakcji UMFME powodowało znaczące zmiany we wszystkich badanych parametrach zwierząt doświadczalnych (w porównaniu do grupy kontrolnej z wywołaną cukrzycą). Wartość $\mathrm{IC}_{50}$ dla frakcji UMFME wynosiła 19,30 $\pm 1,1 \mu \mathrm{g} / \mathrm{ml}$ w badaniu hamowania PTP1B oraz $13,11 \pm 0,7 \mu \mathrm{g} / \mathrm{ml}$ w badaniu działania antyagregacyjnego.

Wnioski: Otrzymane wyniki badań wskazują, że frakcja UMFME z liści N. stellata wykazuje aktywność przeciwcukrzycową i antyagregacyjną.

Słowa kluczowe: STZ-NAD, hamowanie PTP1B, indukcja ADP, metoda co-TLC, histopatologia 